\title{
THE EFFECT OF HYPERVITAMINOSIS A ON OPENING OF THE VAGINAL MEMBRANE IN THE RAT
}

\author{
GIORA MAVLIGIT AND GERSHON GITLIN \\ Department of Anatomy, The Hebrew University-Hadassah Medical School, \\ Jerusalem, Israel
}

(Received 14th April 1970)

\begin{abstract}
Summary. Opening of the vaginal membrane in rats occurred earlier in animals receiving large doses of vitamin $\mathrm{A}$ than in control animals receiving olive oil.
\end{abstract}

Breakdown of the rat's vaginal membrane is heralded by development of cornification centres within the stratified squamous epithelium composing the membrane (Haldeman, 1921). Vesicles containing desquamated, cornified material and leucocytes appear; these enlarge and coalesce to form a lumen.

Vitamin A deficiency is associated with squamous metaplasia and cornification of various epithelia (Wolbach \& Howe, 1928; Salley \& Bryson, 1957; Hicks, 1968) and with prolonged cornification in the rat vagina (Evans \& Bishop, 1922). Vitamin A excess inhibjts keratinization and produces mucous metaplasia in vivo and in vitro (Fell \& Mellanby, 1953; Lasnitzki, 1958; Bern \& Lawrence, 1962; Rothberg, 1967; Polliack \& Levij, 1968).

Premature opening of the rat's vaginal membrane follows the administration of oestrogen (Gurtis \& Doisy, 1931). On vaginal epithelium of the adult rat, vitamin A, either topically applied (Kahn, 1954) or orally administered (Hohlweg, 1951), appears to exert an effect antagonistic to that of oestrogen. A similar effect has been noted on mouse vaginal epithelium in vitro (Lasnitzki, 1961).

The present investigation was undertaken to see whether large doses of vitamin $A$ in the rat could affect vaginal opening, in which process keratinization plays a central rôle.

In the first experiment, vaginal opening occurred earlier in the experimental animals than in the controls. This was unexpected and the experiment was therefore repeated twice, with slight modifications; the results in both these instances were similar to those in the first experiment.

All animals were of the Hebrew University Sabra strain of albino rats.

In Exp. 1, from the age of 29 days, each experimental animal received 37,500 i.u. of vitamin A every 3 days, in the form of $0.3 \mathrm{ml}$ of Avitan (Vitamin A palmitate in olive oil. Zori Pharmaceutical and Chemical Industries, Tel-Aviv). Administration was by means of a narrow polyethylene tube which was passed into the stomach. 
In Exp. 2, the animals were 23 days old and weighed $38 \pm 1 \mathrm{~g}$ when received. From the age of 26 days, each was given 30,000 i.u. of vitamin A subcutaneously every 3 days, in the form of $0.1 \mathrm{ml}$ of Avipur (Vitamin A palmitate in olive oil. Taro Pharmaceutical Industries, Haifa).

In Exp. 3, the animals were 15 days old and weighed $27 \pm 1 \mathrm{~g}$ when received. Vitamin A administration was started when they were 18 days old. Dosage and route of administration were as in Exp. 2.

In each experiment, the controls received the same volume of olive oil by the same route as the experimental animals.

All animals were observed once daily. The commencement of vaginal opening was seen as a small central or paracentral perforation (Stage 1) which enlarged laterally until complete vaginal opening was evident (Stage 2).

In all three experiments, Stages 1 and 2 of vaginal opening occurred earlier in the experimental animals than in the controls (Table 1). The differences are statistically significant in all instances. At the younger age (Exp. 3), the difference between experimental and control groups was smaller than in Exps 1 and 2. This may imply that younger animals are less sensitive to excess vita$\min \mathrm{A}$.

TABLE 1

AGE AT VAGINAL OPENING IN RATS REGEIVING LARGE DOSES OF VITAMIN A

\begin{tabular}{|c|c|c|c|c|c|c|c|c|}
\hline \multirow{2}{*}{$\begin{array}{c}\text { Exp. } \\
\text { No. }\end{array}$} & \multicolumn{2}{|c|}{$\begin{array}{l}\text { No. of } \\
\text { animals }\end{array}$} & \multicolumn{3}{|c|}{ Stage 1} & \multicolumn{3}{|c|}{ Stage 2} \\
\hline & Vit. $A$ & Controls & Vit. $A$ & Controls & $\mathbf{P}$ & Vit. $A$ & Controls & $\mathbf{P}$ \\
\hline $\begin{array}{l}1 \\
2 \\
3\end{array}$ & $\begin{array}{r}7 \\
7 \\
19\end{array}$ & $\begin{array}{r}9 \\
15 \\
20\end{array}$ & $\begin{array}{l}44 \cdot 4(2 \cdot 4)^{*} \\
40 \cdot 0(2 \cdot 1) \\
36 \cdot 5(3 \cdot 2)\end{array}$ & $\begin{array}{l}53 \cdot 0(3.8) \\
49 \cdot 5(5 \cdot 5) \\
40 \cdot 1(3.8)\end{array}$ & $\begin{array}{l}<0.001 \\
<0.001 \\
<0.005\end{array}$ & $\begin{array}{l}45 \cdot 4(2 \cdot 2) \\
43 \cdot 7(1 \cdot 7) \\
38 \cdot 7(3 \cdot 3)\end{array}$ & $\begin{array}{l}54 \cdot 5(3 \cdot 3) \\
55 \cdot 0(5 \cdot 7) \\
41 \cdot 5(4 \cdot 0)\end{array}$ & $\begin{array}{l}<0.001 \\
<0.001 \\
<0.02\end{array}$ \\
\hline
\end{tabular}

Stage 1. Central or paracentral perforation of vaginal membrane.

Stage 2. Complete vaginal opening.

* Mean age (in days) at vaginal opening. S.D. in parentheses.

In view of the evidence quoted above, it was anticipated that vitamin $\mathrm{A}$ administration would delay vaginal opening. The earlier opening of the vagina in the vitamin A-treated rats is difficult to interpret. Of interest in this connection are the experiments of Reiter (1965) on the development of squamous keratinizing metaplasia in the uteri of oestrogen-treated rats. He found that simultaneous administration of large doses of vitamin A did not prevent the development of such lesions. Recent studies on carcinoma of the hamster cheek pouch induced by topical application of 9,10-dimethyl-1,2-benzanthracene (DMBA) are also significant. Application of vitamin A potentiated the action of DMBA (Polliack \& Levij, 1969); in castrated males, oestrogen had an effect similar to that of vitamin A (Polliack, Charuzy \& Levij, 1969). These authors have suggested that the similarity in the action of vitamin $A$ and oestrogen may be related to the effect of these substances on cellular and subcellular membranes. Vitamin A is known to increase the permeability of such membranes, with release of proteolytic lysosomal enzymes (Dingle \& Lucy, 
1965; Dingle, Sharman \& Moore, 1966; Brandeis \& Anton, 1966). Bangham, Standish \& Weissmann (1965) found that stilboestrol and a number of sex hormones increase the permeability of concentric lamellae of phospholipids which have characteristics similar to those of biological membranes. It is conceivable that intracellular and extracellular liberation of proteolytic enzymes may have been a factor in causing earlier breakdown of the vaginal membrane in the vitamin A-treated rats in the present experiments.

We wish to thank Dr J. Gohen and Dr E. Peritz for generous help in the statistical aspects of the work and Mrs S. Hajman for much technical assistance.

\section{REFERENGES}

Bangham, A. D., Standish, M. M. \& Werssmann, G. (1965) The action of steroids and streptolysin S on the permeability of phospholipid structures to cations. F. molec. Biol. 13, 253.

Bern, H. A. \& LAwrence, D. J. (1962) Infuence of vitamin $A$ on keratinization. In: Fundamentals of Keratinization. Eds. E. O. Butcher and R. F. Sognaes. Publ. No. 70. Am. Assoc. Adv. Sc.

BRANDEIs, D. \& Anton, E. (1966) The role of lysosomes in cellular lytic processes. III. Electron histochemical changes in mammary tumours after treatment with cytoxan and vitamin A. Lab. Invest. 15, 987.

Curris, J. M. \& Dorsy, E. A. (1931) The bio-assay of theelol. F. biol. Chem. 91, 647.

Dingle, J. T. \& LucY, J. A. (1965) Vitamin A, carotenoids and cell function. Biol. Rev. 40, 422.

Dingle, J. T., Sharman, I. M. \& Moore, T. (1966) Nutrition and lysosomal activity. Biochem. F. 98, 476.

Evans, H. M. \& Bishop, K. S. (1922) On an invariable and characteristic disturbance of reproductive function in animals reared on a diet poor in fat soluble vitamin A. Anat. Rec. 23, 17.

Fell, H. B. \& Mellandy, E. (1953) Metaplasia produced in cultures of chick ectoderm by high vitamin A. 7. Physiol., Lond. 119, 470.

Haldeman, K. O. (1921) The method of opening of the vagina in the rat. Anat. Rec. 21, 60.

Hraks, R. M. (1968) Hyperplasia and cornification of the transitional epithelium in the vitamin A deficient rat. Changes in the fine structure of the cells. F. Ultrastruct. Res. 22, 206.

Honlweg, W. (1951) Ueber die Hemmung der Oestrusreaktion durch Vitamin-A-Ueberdosierung. Klin. Wschr. 29, 193. Quoted by Kahn (1954).

KAHN, R. H. (1954) Effect of locally applied vitamin A and estrogen on the rat vagina. Am. J. Anat.95, 309.

LASNITZKI, I. (1958) The effect of carcinogens, hormones and vitamins on organ cultures. Int. Rev. Cytol. 7, 79.

LASNTTZKr, I. (1961) Effect of excess vitamin A on the normal and oestrone-treated mouse vagina grown in chemically defined medium. Expl Cell Res. 24, 37.

Polliack, A., Gharuzy, I. \& Levij, I. S. (1969) The effect of oestrogen on 9,10-dimethyl-1,2-benzanthracene (DMBA)-induced cheek pouch carcinoma in castrated and non-castrated male Syrian golden hamsters. Br. F. Cancer, 23, 781 .

Polliack, A. \& LevJ, I. S. (1968) Epithelial atypia in the hamster cheek pouch, induced by topical application of vitamin A. Oncology, 22, 129.

Polliack, A. \& LeviJ, I. S. (1969) The effect of topical vitamin A on papillomas and intraepithelial carcinomas induced in hamster cheek pouches with 9,10-dimethyl-1,2-benzanthracene. Cancer Res. 29, 327.

RETTER, R. J. (1965) Estrogen-induced uterine metaplasia in rats given oral supplements of vitamin A. Experientia, 21, 207.

RothвERG, S. (1967) The cultivation of embryonic chicken skin in a chemically defined medium and the response of the epidermis to excess of vitamin A. F. invest. Derm. 49, 35 .

SAlley, J. J. \& Bryson, W. F. (1957) Vitamin A deficiency in the hamster. F. dent. Res. 36, 935.

Wolbach, S. B. \& Howe, P. R. (1928) Vitamin A deficiency in the guinea pig. Archs Path. 5, 239. 